\title{
AVIATION LEGAL ISSUES IN INDONESIA AND THAILAND: TOWARDS BETTER PASSENGERS' RIGHTS IN ASEAN
}

\author{
Ridha Aditya Nugraha* and Lalin Kovudhikulrungsri**
}

\author{
* Air Power Centre of Indonesia \\ **Universiteit Leiden, International Institute of Air and Space Law, Leiden University
}

\section{Article Info}

Received : 22 February 2016 | Received in revised form : 18 February 2017 | Accepted : 23 March 2017

Corresponding author’s e-mail : ra.nugraha@apci.asia, l.k.kovudhikulrungsri.2@umail.leidenuniv.nl

\begin{abstract}
The aviation business in the ASEAN region has shown significant growth during the last decade. With the enactment of ASEAN Open Skies, there is no doubt that intra-ASEAN flights will continue to increase rapidly with Indonesia and Thailand experiencing significant effects from such development. Considering current rapid market capitalizatio $n$, there is an urgency to establish equilibrium between commercial and passengers' rights. Flight delays, cancellations, and denied boarding, either on domestic or international flights, are the main airline passengers' rights issues that are always relevant and must be kept up-to-date with recent developments. In the context of the so-called integrated ASEAN skies, the urgency to establish a uniform legal framework on passengers' rights has become essential. Learning from the current international legal framework, namely the Warsaw Convention, the Montreal Convention, and EU Regulation No. 261/2004, they could present the source of best solution. Considering that the latter was established by another regional initiative, it could be a particularly valuable guide for ASEAN, even though the current integration level of the EU and ASEAN are quite different. Also of importance, the bomb threat hoax phenomenon within Indonesia and Thailand shall also be discussed. Passengers' rights must also be protected against the implications of such irresponsible acts.
\end{abstract}

Keywords: bomb threat, compensation, delay, flight cancellation, denied boarding passengers' rights

\begin{abstract}
Abstrak
Bisnis penerbangan di ASEAN telah tumbuh secara signifikan dalam dekade terakhirini. Tidak dapat dipungkiri bahwa dengan berlakunya ASEAN Open Skies, maka jumlah penerbangan intra-ASEAN akan semakin meningkat; dan tentunya Indonesia dan Thailand akan mengalami dampak signifikan dari perkembangan tersebut. Melihat gencarnya kapitalisasi pasar yang terjadi dalam bisnis penerbangan, muncul suatu urgensi untuk menemukan titik ekuilibrium antara perlindungan hak-hak penumpang pesawat terbang dengan kepentingan komersial. Keterlambatan atau pembatalan penerbangan, hingga penolakan untuk mengangkut penumpang dalam suatu rute penerbangan, baik pada rute domestik maupun internasional, merupakan isu-isu utama yang relevan terkait perihal hak-hak penumpang; dimana seharusnya ketentuannya selalu disesuaikan dengan perkembangan terkini. Dalam konteks semakin terintegrasinya langit ASEAN, maka semakin nyatalah urgensi akan dibentuknya kerangka hukum yang mampu melindungi hak-hak para penumpang pesawat terbang. Salah satu langkah terbaik yang dapat ditempuh adalah dengan mempelajari kerangka hukum internasional yang telah ada, antara lain Konvensi Warsawa, Konvensi Montreal, dan Regulasi Uni Eropa No. 261/2004. Mengingat regulasi yang terakhir ini dibentuk oleh suatu kerjasama regional, sudah seharusnya ASEAN dapat belajar banyak darinya; terlepas adanya perbedaan bentuk dan tingkat integrasi antara Uni Eropa dan ASEAN. Satu hal yang juga tidak kalah penting, tulisan ini juga membahas mengenai fenomena maraknya bercanda bom di Indonesia dan Thailand. Hak-hak penumpang juga harus dilindungi dari dampak tindakan yang tidak bertanggungjawab ini.
\end{abstract}

Kata kunci: ancaman bom, kompensasi, penundaan, pembatalan penerbangan, hak penumpang yang ditolak 


\section{INTRODUCTION}

Liberalization of air services in the Association of Southeast Asian Nations (hereinafter referred to as ASEAN) region, known as the ASEAN Single Aviation Market (hereinafter referred to as ASAM) or ASEAN Open Skies, fundamentally benefits passengers not only by removing limitations on the number of international flights within the member states but also on account of lower airfares. Simultaneously, this creates more competition among the member states' airlines. Correlating to the increasing number of air traffic is the concern over rules applying to these international flights, especially rules on passengers' rights.

The International Civil Aviation Organization (ICAO) has brought attention to different rules on passengers' rights in international air transport among countries and adopted a view that in order to avoid any legal uncertainty, states should minimize the differences in the contents and application of regulations. ${ }^{1}$ Passengers' rights, as seen from its expression, is certainly favor of consumers. On the other hand, however, it is also necessary for airlines in terms of branding, marketing, and reputation. ${ }^{2}$ Accordingly, this paper also aims to eliminate as many differences in rules on passengers' rights in ASEAN with a view to balance rights and duties between passengers and airlines. Passengers' rights in this paper, however, are limited only to the rights in the event of flight disruptions, namely, flight delays, denied boarding, and flight cancellations.

As ASEAN does not have legislative powers, no legal framework on this issue has been passed even though a study raises concerns that a policy on consumer rights in the aviation sector should be developed. ${ }^{3}$ This paper discusses relevant domestic laws in Indonesia and Thailand respectively, and the current private international law on international air carriage. Bomb threat hoax, a trending incident in both Indonesia and Thailand, and its linkage to flight disruptions is also examined. Finally, this paper proposes an option for harmonizing or mitigating differences among ASEAN member states by studying an initiative by the European Union (EU) as an example of another regional initiative.

\section{BOMB THREATS AND INNOCENT PASSENGERS' RIGHTS}

\section{A. Indonesia: Too Many Irresponsible Hoaxes}

Irresponsible hoax about bringing a bomb on-board an aircraft has become rather widespread among Indonesian airline passengers recently. There were fifteen cases related to hoaxes of a bomb threat between 2015-2016. ${ }^{4}$ There have been various reasons underlying such irresponsible act, ranging from making a hoax 'accidentally' to expressing anger due to long delay, security check, and in response to the unpleasant behavior of flight attendants. Fortunately, such infamous trend of hoax does not appear in other transportation modes, such as railway and sea travel. Otherwise the ability to operate reliable transportation in this country would become unimaginable.

The Indonesian Aviation Law ${ }^{5}$ had come into force six years before bomb threat

1 Ruwantissa Abeyratne, Regulation of Air Transport: The Slumbering Sentinels (Heidelberg: Springer, 2014), p. 85.

${ }^{2}$ Ruwantissa Abeyratne, Aeronomics and Law: Fixing Anomalies (Heidelberg: Springer, 2012), p. 104.

3 Peter Forsyth, et. al., Preparing ASEAN for Open Sky, Final report, AADCP Regional Economic Policy Support Facility. Research Project 02/008, February 2004, p. 118.

${ }^{4}$ HukumOnline, "Waspada! Bercanda Soal Bom di Pesawat Bisa Dipenjara [Beware! Bomb Hoax on Board of an Airplane Can End up in Prison ]," http://www.hukumonline.com/berita/baca/lt568e24c702bd1/ waspada-bercanda-soal-bom-di-pesawat-bisa-dipenjara, accessed February 14, 2016.

${ }^{5}$ Indonesia, Undang-Undang tentang Penerbangan (Law regarding Aviation), UU No. 1 Tahun 2009, LN 
hoaxes became a trend. The law refers to bomb threat hoaxes as act of providing false information ${ }^{6}$, which is deemed as unlawful interference. Sanction against providing false information is already regulated in the Indonesian Aviation Law. Further details are indicated in the table below: ${ }^{7}$

Table 1

\begin{tabular}{l|lrl}
\hline \multicolumn{1}{c|}{ Degree of Damage } & \multicolumn{2}{c|}{ Sanctions } \\
\hline $\begin{array}{l}\text { Providing false information (in this case meaning a bomb threat hoax) } \\
\text { which endangers aviation safety }\end{array}$ & $\begin{array}{l}\text { Maximum } \\
\text { imprisonment }\end{array}$ & (one) year \\
\hline $\begin{array}{l}\text { Providing false information which results in aircraft accident or } \\
\text { property loss }\end{array}$ & $\begin{array}{l}\text { Maximum } \\
\text { imprisonment }\end{array}$ & (eight) years \\
\hline Providing false information which causes fatalities & $\begin{array}{l}\text { Maximum 15 (fifteen) years } \\
\text { imprisonment }\end{array}$ \\
\hline
\end{tabular}

Fortunately, there is not any loophole for this kind of irresponsible act within the Indonesian Aviation Law. Any unlawful act can be legally processed at any given time. In fact, Ignasius Jonan, the current Minister of Transportation, has spoken up firmly guaranteeing that any infringement shall be processed according to the Indonesian Aviation Law. ${ }^{8}$ Following up on the said statement, the case of Mr. Russel was one of the few that could still be traced online. Last December 2015, he was detained after a bomb threat hoax in an Ambon-Langgur flight, on-board Wings Air IW-1504 flight. ${ }^{9}$ He has even become a suspect in the said case. However, so far there has not been a single court decision, and neither have been from the other fourteen cases that occurred last year. It leaves an open question concerning law enforcement, whatever the reason behind it. The Batik Air ID 6179 incident $^{10}$, still related to a bomb threat hoax, involving a former army high officer's son that ended with discontinuing the legal process has worsened the public opinion on law enforcement in dealing with this issue.

It is interesting to see there is not any punitive fine specified in Article 437 of the Indonesian Aviation Law, regardless of the severity of the damages caused. It means any irresponsible hoax which endangers aviation safety shall lead to imprisonment, without the possibility of an alternative of paying a fine. However, consequently, when

No. 1 Year 2009 (Law No. 1, SG. No. 1 Year 2009).

${ }^{6}$ Ibid, Art. 344.

7 Indonesia, Undang-Undang tentang Penerbangan (Law regarding Aviation), UU No. 1 Tahun 2009, LN No. 1 Year 2009 (Law No. 1, SG. No. 1 Year 2009) The Indonesian Aviation Law, Art. 437.

8 Estu Suryowati, "Menhub Pastikan yang Bercanda Bawa Bom di Bandara Tetap Diproses Hukum [Minister of Transportation Reassures that the Legal Process against Enactors of Bomb Hoax on Airflight Will Continue]," http://bisniskeuangan.kompas.com/read/2016/01/16/150026826/Menhub.Pastikan. yang.Bercanda.Bawa.Bom.di.Bandara.Tetap.Diproses.Hukum, accessed February 14, 2016.

9 Satu Maluku, "Bercanda Bom, Penumpang Tujuan Langgur Terancam Penjara 9 Tahun [Joking about bomb, a passenger bound for Langgur facing jail sentence of 9 years]," http://satumaluku. com/2015/12/05/bercanda-bom-penumpang-tujuan-langgur-terancam-penjara-9-tahun/, accessed February $14,2016$.

${ }^{10}$ Siwalimanews, “Usut Kasus Bercanda Bawa Bom di Pesawat: DPRD Desak Polisi Periksa Anak Nono Sampono [Investigating the Case of Bomb Hoax on Airplane: The Regional House of Representatives Urges the Police to Examine the Son of Nono Sampono]," http://www.siwalimanews.com/post/dprd desak polisi periksa anak nono sampono, accessed February 15, 2016; Satu Maluku, "Kasus Candaan Bom, Polisi Didesak Periksa Anak Nono Sampono [The bomb-joke case, Police urged to investigate Nono Sampono's son]," http://satumaluku.com/2015/12/08/kasus-candaan-bom-polisi-didesak-periksa-anak-nono-sampono/ accessed February 15, 2016. 
law enforcement is in any doubt, perpetrators are able to walk away without having to face any consequences. It would be better to make them pay for their irresponsible act, which would mean income for the state.

\section{B. Thailand}

In 2014, the then Director of the Department of Civil Aviation of Thailand accepted that a hoax bomb threat to domestic air services in Thailand had rarely happened and was seldom reported in the news. ${ }^{11}$ Before the entry into force of the new Act on Certain Offences Against Air Navigation of $2015^{12}$ (hereinafter the "Act of 2015"), there has never been a case filed with the Supreme Court of Thailand on this issue. One of the main reasons is that the sanction under the Penal Code, the former applicable law in case of a bomb hoax, is so low that it is normally not allowed to appeal to the higher court.

However, under the new Act of 2015, a person can be jailed and fined for a maximum amount of THB200,000 (approximately USD5,600). This is in addition to potential civil litigation. Even though as of February 2016 there was no final judgment rendered by the court on bomb hoax under the Act of 2015 , there was a high chance of a case. From November 2015 to January 2016, at least three bomb threats have been reported in the news. ${ }^{13}$ In other words, there was one hoax per month, excluding any possible hoaxes which may have not received publicity. It is assumed that the serious sanction of the Act of 2015 is one of the causes which makes a bomb hoax newsworthy. Taking one of the three cases as an instance, a 23-year-old man, ironically working in the transportation sector, who confessed to making a bomb hoax to flirt with a flight attendant who was helping a passenger to place a bag in the overhead cabin is now facing a criminal charge and a civil lawsuit filed by an airline as well as a disciplinary punishment by his employer. ${ }^{14}$

\footnotetext{
11 “Air Asia Bomb Threat," http://www.thairath.co.th/content/446016, accessed February 17, 2016.

12 Thailand, Act on Certain Offences Against Air Navigation, B.E. 2558 (2015) (Royal Gazette No. 132 Part 10 Kor).

13 The Jakarta Post, “Lion Air Flight Canceled after Passenger Makes Bomb Joke," http://www.thejakartapost.com/news/2015/11/02/lion-air-flight-canceled-after-passenger-makes-bomb-joke.html, accessed February 17, 2016; Nation Multimedia "Bangkok Airways Flight Delayed Following Bomb Hoax," http://www.nationmultimedia.com/breakingnews/Bangkok-Airways-flight-delayed-following-bombhoax-30274777.html, accessed February 17, 2016; The Phuket News "Thai Man, 20, Arrested, Charged for Sarcastic 'Shoe Bomb' Remarks During Airport Security Inspection,” http://www.thephuketnews. com/thai-man-20-arrested-charged-for-sarcastic-shoe-bomb-remarks-during-airport-security-inspection-55727.php, accessed February 17, 2016.

14 Coconuts, "Thai Lion Air Seeks THB2 Million Compensation from Flirty Bomb Joker," http://bangkok.coconuts.co/2015/11/04/lion-air-ceo-seeks-thb2-million-compensation-flirty-bomb-joker, accessed February 17, 2016.
} 


\section{Table $2^{15}$}

\section{Degree of Damage under the Act of 2015}

Providing false information which alarms persons in an airport or on board an aircraft in flight

Providing false information which endangers the safety of an aircraft in flight

\section{Sanctions}

Not exceeding five years imprisonment or not exceeding THB200,000 fine (approximately USD5,600) or both

Five to fifteen years imprisonment or THB200,000 to 600,000 fine (approximately USD5,600 to 16,800 ) or both

Same punishment as the offender of such offence

Being an accessory to the commission of an offence

Attempting to commit the offence Same punishment as the offender of such offence

Generally, making a bomb hoax is not a new criminal offence in Thailand since it has been codified in the Thai Penal Code. ${ }^{16}$ Article 384 of Thai Penal Code provides a sanction of imprisonment not exceeding one month or fine not exceeding THB10,000 (approximately USD280). The interesting issue is that the Act of 2015 adds this offence specifically for air transport and significantly increases the sentence. As seen from Table I and II, before the enactment of the Act of 2015, a bomb threat was a petty offence. The Act on Certain Offences Against Air Navigation of 1978 (hereinafter the "Act of 1978"), repealed by the Act of 2015, only covered incidents when the safety of an aircraft in flight was harmed. ${ }^{17}$ Accordingly, in the event of a bomb hoax, the entry into force of the Act of 2015 increases the level of sanctions in two aspects. First, it increases the term of imprisonment and the amount of a fine. Second, the scope is broader because the first paragraph of Article 22 the Act of 2015 expands to include a bomb hoax made at an airport.

\section{Table $3^{18}$}

\begin{tabular}{l|l}
\hline \multicolumn{1}{c|}{ Degree of Damage under the Act of 1978 } & \multicolumn{1}{c}{ Sanctions } \\
\hline $\begin{array}{l}\text { Providing false information which endangers the safety of an } \\
\text { aircraft in flight }\end{array}$ & $\begin{array}{l}\text { Between five to twenty years } \\
\text { imprisonment }\end{array}$ \\
\hline $\begin{array}{l}\text { Providing false information which endangers the safety of an } \\
\text { aircraft in flight and causes grievous bodily harm to a person }\end{array}$ & $\begin{array}{l}\text { Between ten to twenty years } \\
\text { imprisonment }\end{array}$ \\
\hline $\begin{array}{l}\text { Providing false information which endangers the safety of an } \\
\text { aircraft in flight and causes death to a person }\end{array}$ & $\begin{array}{l}\text { Between fifteen to twenty } \\
\text { years imprisonment or life } \\
\text { imprisonment }\end{array}$ \\
\hline
\end{tabular}

It is without doubt that this Act of 2015 applies to domestic flights. If it regulated incidents for only these routes, the possibility of applying this law to a foreigner would not be high. Nevertheless, in reality, as evident from the three cases reported in the news, despite the fact that they occurred on domestic air services, one of the hoaxes was made by a foreigner who may not know how severe the sentence for this charge is. It needs to be mentioned that under the Thai Penal Code, ignorantia juris non excusat, a legal principle holding that ignorance of the law excuses no one, is adhered to. ${ }^{19}$ What is worse for foreigners is that the jurisdiction includes international flights

\footnotetext{
15 Thailand, "Act of 2015," arts. 22-24.

16 Thailand, Penal Code, B.E. 2499 (1956) (Royal Gazette No. 73, Part 95, Special Issue Page 1), art. 384.

17 Thailand, Act on Certain Offences Against Air Navigation, B.E. 2521 (1978) (Royal Gazette No. 95, Part 87 Special Issue).

${ }^{18}$ Thailand, "Act of 1978," arts. 9-10

19 “Thai Penal Code," art. 64.
} 
and foreign airlines in some circumstances even when a person made a hoax outside the territory of Thailand. One of such situations is when a bomb threat is committed on board a Thai aircraft while such aircraft is not in the territory of Thailand, such as an international flight. ${ }^{20}$ The jurisdiction of such act includes a case when offence is committed on board a foreign aircraft which lands in the territory of Thailand with the alleged offender on board. ${ }^{21}$

\section{Is There Any Protective Measure for Innocent Passengers?}

A bomb hoax is criminalized under the Indonesian and Thai legal framework respectively. Regardless of the level of punishment in each of these two countries, the essence of the legal framework is to inhibit a person from making an ill-conceived attempt at humor. However, if a bomb threat still occurs against an aircraft, they shall follow the procedures to search for a bomb, such as evacuating passengers from the aircraft and inspecting all baggage.

Turning to the concerns of fellow passengers, after being evacuated, amid being frightened by a bomb threat, they have to stray at an airport without any knowledge as to when they can travel further, or even if another transit or connecting flight will be available. It must be highlighted that this procedure may lead to either flight delay or flight cancellation. ${ }^{22}$ None of the abovementioned laws focus on innocent passengers; hence, the existing legal framework on flight disruptions plays a critical role in mitigating this issue for innocent passengers during a bomb threat incident. The law will be analyzed further in the section below.

\section{FLIGHT DELAY, CANCELLATION, AND DENIED BOARDING: AIRLINES' CLASSICAL ISSUES}

\section{A. Indonesia}

Recently, just one year ago, following numerous flight delays, Minister of Transportation Regulation No. $89^{23}$ (hereinafter referred to as "Indonesian Regulation No. 89") was enacted. The regulation is aimed to protect airline passengers' rights travelling on domestic routes by establishing a delay management standard. Furthermore, the regulation protects airline passengers in more than just mere delay matters, but also on denied boarding and flight cancellation issues. ${ }^{24}$

According to Indonesian Regulation No. 89, delay is defined as "time differences between the scheduled departure or arrival time with its actual realization". ${ }^{25}$ Such a pro-passenger provision makes it more difficult for the airlines to neglect their duty.

20 Thailand, "Act of 2015," art. 42.

21 Thailand, "Act of 2015," art. 44(1).

22 Nation Multimedia, "Bangkok Airways Flight Delayed Following Bomb Hoax," http://www.nationmultimedia.com/breakingnews/Bangkok-Airways-flight-delayed-following-bomb-hoax-30274777.html, accessed February 17, 2016; The Jakarta Post, "Lion Air Flight Canceled after Passenger Makes Bomb Joke," http://www.thejakartapost.com/news/2015/11/02/lion-air-flight-canceled-after-passenger-makesbomb-joke.html, accessed February 17, 2016.

${ }^{23}$ Indonesia, Peraturan Menteri Perhubungan tentang Penanganan Keterlambatan Penerbangan (Delay Management) Pada Badan Usaha Angkutan Udara Niaga Berjadwal di Indonesia (Minister of Transportation Regulation regarding Delay Management on Scheduled Commercial Airline in Indonesia), Permenhub No. 89 Tahun 2015, BNRI No. 716 Year 2015 (Minister Regulation No. 89 Year 2015, SG No. 716 Year 2015); hereinafter referred as "Indonesian Regulation"

${ }^{24}$ Ibid., art. 2.

25 Ibid., art. 1(6). 
Under this regulation, flight delay is classified into six categories ${ }^{26}$ which can be seen below.

Table 4

\begin{tabular}{|c|c|c|}
\hline Delay Categories & Condition & Compensation \\
\hline First & $\begin{array}{l}30 \text { up to } 60 \\
\text { minutes delay }\end{array}$ & Providing refreshing drinks. \\
\hline \multirow[t]{2}{*}{ Second } & $\begin{array}{l}61 \text { up to } 120 \\
\text { minutes delay }\end{array}$ & Providing a snack box set. \\
\hline & & $\begin{array}{l}\text { The passenger can be assigned to the next flight or his/her ticket } \\
\text { is refunded. }\end{array}$ \\
\hline \multirow[t]{2}{*}{ Third } & $\begin{array}{l}121 \text { up to } 180 \\
\text { minutes delay }\end{array}$ & Providing a heavy meal. \\
\hline & & $\begin{array}{l}\text { The passenger canbe assigned to the next flight or his/her ticket } \\
\text { is refunded. }\end{array}$ \\
\hline \multirow[t]{2}{*}{ Fourth } & $\begin{array}{l}181 \text { up to } 240 \\
\text { minutes delay }\end{array}$ & Providing a snack box set and heavy meal. \\
\hline & & $\begin{array}{l}\text { The passenger canbe assigned to the next flight or his/her ticket } \\
\text { is refunded. }\end{array}$ \\
\hline \multirow[t]{3}{*}{ Fifth } & $\begin{array}{l}\text { more than } 240 \\
\text { minutes delay }\end{array}$ & $\begin{array}{l}\text { IDR300,000 (approximately USD25) in the form of cash, } \\
\text { redeemable voucher, or bank account transfer. It must be } \\
\text { processed by no later than } 3 \times 24 \text { hours after the occurrence of } \\
\text { the delay. }\end{array}$ \\
\hline & & $\begin{array}{l}\text { Airlines must provide accommodation (if necessary) for a delay } \\
\text { of more than } 6 \text { (six) hours. }\end{array}$ \\
\hline & & $\begin{array}{l}\text { The passenger canbe assigned to the next flight or his/her } \\
\text { ticket is refunded. It shall be in the form of cash (if the ticket is } \\
\text { purchased by cash) or transferred to the passenger's credit card } \\
\text { account within } 30 \text { (thirty) calendar days. }\end{array}$ \\
\hline \multirow[t]{2}{*}{ Sixth } & flight cancellation & Either being assigned to the next flight or a refunded ticket. \\
\hline & & $\begin{array}{l}\text { In the case of refunded ticket, it shall be in form of cash (if the } \\
\text { ticket is purchased by cash) or transferred to the passenger's } \\
\text { credit card account within } 30 \text { (thirty) calendar days. }\end{array}$ \\
\hline
\end{tabular}

It must be highlighted that in the event of being assigned to another flight, regardless of the category, the airline shall pay for any price differences in the event of service reduction from business class to economy class. ${ }^{27}$ A clear message emanating from this regulation is that passengers must not be burdened with any extra fees. Time limits for ticket refund and delay compensation are also being set up, closing a loophole in terms of postponing the payment or transfer. It is interesting to note that the insurance industry is also being involved specifically in dealing with the fifth delay category. ${ }^{28}$ The insurance industry's involvement is considered a way to guarantee an adequate amount of funds to compensate passengers. It is thus quite evident that numerous preventive measures are being established by the government with a view to protecting passengers' rights.

Indonesian Regulation No. 89 provides for no compensation for any delay caused

\footnotetext{
${ }^{26}$ Ibid., arts. 3(1), 10, and 11.

27 Ibid., art. 10.

28 Ibid., art. 12.
} 
by force majeure or airport operational factor. The former applies globally, from national laws to regional initiative regulation. Compensation shall only be granted for delay caused by the airline management's fault, namely due to i) tardiness of pilot, co-pilot, and crew; ii) tardiness of the catering service; iii) tardiness of ground service; iv) waiting for last check-in, transfer or connecting (flight) passengers; and v) unpreparedness of the aircraft. ${ }^{29}$ Generally the delay compensation provisions seem fair enough, however they fail to address the current situation of airport overcapacity. It has become public knowledge that major Indonesian airports are operating over their capacity, including the Soekarno-Hatta International Airport (CGK). ${ }^{30}$ With a view to such situation, the provision excluding delay compensation due to airport operational factor needs to be reviewed further. There is a potential for airlines to use this provision, such as departure slot time or refueling issues, to evade the management's responsibility. Supposedly an airline should not always be suspected and blamed for every delay that occurs. However, there has been increasing public distrust towards airlines' poor performance due to lack of law enforcement, namely failure to impose heavy sanctions on neglectful airlines.

Indonesian Regulation No. 89 takes a more generous attitude towards airlines. If a bomb threat occurs, any delay or cancellation caused is considered beyond the airline's control. Thus there is no fault on the airline's part. As a consequence, passengers are not entitled to any right to care, refund, reschedule or compensation. In Indonesia, innocent passengers' rights are not protected against bomb threats or any irresponsible passenger making a bomb hoax.

When it comes to international flights, there are more than one legal frameworks dealing with the delay issue. At least when the airline departs from an Indonesian airport, an obligation to take care of the passengers with refreshing drinks, a snack box, a heavy meal, and even overnight accommodation, i.e. "a right to care" occurs. However, when it comes to compensation matters, it appears that Indonesian Regulation No. 89 is put aside due to various reasons, ranging from 'technical' issues of distributing the cash compensation up to a chance for higher amount of compensation at the destination, either according to national law or international convention.

Speaking of delays, currently it is Lion Air who has been receiving the most public attention. The airline's numerous delay cases have become a phenomenon in the recent years. ${ }^{31}$ Lion Air has had numerous issues with fulfilling its service obligation under the regulation, ranging from absence of its officers when delay occurs ${ }^{32}$ to

${ }^{29}$ Ibid., art. 5.

30 Hari Cahyono, "Awas, Lampu Kuning Kondisi Aviasi Indonesia [Watchout, The Yellow Light of Indonesian Aviation Condition]," http://beritatrans.com/2016/02/11/awas-lampu-kuning-kondisi-aviasiindonesia/, accessed February 15, 2016; Bandara Online, "10 Bandara Angkasa Pura II Over Kapasitas [10 Angkasa Pura II's airport are overcapacity," http://bandaraonline.com/airport/10-bandara-angkasa-puraii-over-kapasitas, accessed February 15, 2016.

31 Georgia Diebelius, "Pilot Banned from Flying After 'Offering Divorced Air Hostess as Compensation for a Delay on a Flight to Bali," http://www.dailymail.co.uk/travel/travel news/article-3326809/Pilotbanned-flying-offering-divorced-AIR-HOSTESS-compensation-delay-flight-Bali.html, accessed February 15, 2016; HukumOnline, "Lima Kasus Maskapai Penerbangan yang Dibawa ke Pengadilan, [Five Airline Cases Brought to the Court]," http://www.hukumonline.com/berita/baca/lt54d046d9261ac/lima-kasusmaskapai-penerbangan-yang-dibawa-ke-pengadilan, accessed February 15, 2016., accessed 15 February 2016.

32 Robertus Belarminus, "Dikejar-kejar Penumpang, Petugas Lion Air Kabur [Chased by Passengers, Lion Air Officer Escaped]," http://megapolitan.kompas.com/read/2015/02/19/14342341/Dikejar-kejar. Penumpang.Petugas.Lion.Air.Kabur accessed February 16, 2016. Fokus Riau, "Delay 7 Jam, Penumpang Obrak-Abrik Ruang Duty Manager Lion Air [7 Hours Delay, the Passengers Vandalized Lion Air's Duty Manager Room]," http://fokusriau.com/berita-delay-7-jam-penumpang-obrakabrik-ruang-duty-managerlion-air-.html, accessed February 16, 2016. 
problems with fulfillment of delay compensation. ${ }^{33}$ However, serious sanctions are yet to be applied. ${ }^{34}$ Reducing the number of allotted routes or license revocation, two of the heaviest sanctions according to Indonesian Regulation No. 89, seem at the moment to be merely lip service. Questions have arisen as to whether there is a link between sanctions and the airline owner's position within the government, which ultimately dulls the law enforcement that should have taken place.

Following increasing legal awareness among Indonesian airline passengers, some delay and denied boarding cases have ended up at the Indonesian Supreme Court. Most of the time, immaterial damage has become the main objective during these suits, even though it was not always granted in the full amount. ${ }^{35}$ Indeed, this kind of consumer legal pressure needs to be encouraged in order to create a balance between the growing business and the rights of airline passengers.

Ultimately, despite the existence of pro-consumer regulations, the Indonesian government is fully aware of airlines' role in developing the economy. Their potential insolvency due to 'too tight' regulations would mean a disaster. Attempts have been made towards a win-win solution in the form of delay compensation in the amount of IDR300,000 (approximately USD25), by replacing Indonesian Minister of Transportation Regulation No. $77^{36}$ (hereinafter referred to as "Indonesian Regulation No. 77") with Indonesian Regulation No.89. It raises the delay time from four hours to five hours making it eligible for passengers to obtain compensation. It is a relief for the airlines, considering the current airport overcapacity situation and unreliability of available human resources.

\section{B. Thailand}

In Thailand, two pieces of legislation protect passengers in relation to flight disruptions; however, their scope of application is limited and parts of their contents are inconsistent.

The Announcement of the Ministry of Transport on Protection of Passenger Rights

${ }^{33}$ Salman Mardira, "Uang Kompensasi Tak Sesuai, Penumpang Lion Air Protes [Compensation Not Adequate, Lion Air Passnger Protests]," http://news.okezone.com/read/2015/12/01/340/1258703/uangkompensasi-tak-sesuai-penumpang-lion-air-protes?page=1, accessed February 16, 2016; Kompas, "Delay 5 Jam, Lion Air Tak Berikan Kompensasi untuk Penumpang [Five hour delay, Lion Air did not give the compensation for the passengers]," http://nasional.kompas.com/read/2015/01/05/01135611/Delay.5.Jam. Lion.Air.Tak.Berikan.Kompensasi.untuk.Penumpang, accessed 16 February 2016. Suwarjono, "Terlambat 5 Jam, Lion Air Tolak Beri Kompensasi [Delay for 5 hours, Lion Air Refuses to Grant Compensation]," http:// www.suara.com/news/2015/02/23/164731/terlambat-5-jam-lion-air-tolak-beri-kompensasi, accessed February 16, 2016.

34 Erik Purnama Putra, "Menhub Jonan Dituding Takut Hadapi Lion Air [Minister of Transportation Jonan Accused of Being Afraid to Encounter Lion Air]," http://www.republika.co.id/berita/nasional/ umum/15/02/21/nk3rxo-menhub-jonan-dituding-takut-hadapi-lion-air, accessed February 16, 2016; Safyra Primadhyta and Elisa Valenta Sari, "Ignasius Jonan Bebaskan Lion Air dari Sanksi Pembekuan Izin [Ignasius Jonan Releases Lion Air from the Sanction of License Revocation]," http://www.cnnindonesia. com/ekonomi/20150220220007-92-33711/ignasius-jonan-bebaskan-lion-air-dari-sanksi-pembekuanizin/ accessed February 16, 2016; "Lion Air Cuma Kena Sanksi Teguran [Lion Air is only sanctioned with warning]," http://www.gresnews.com/berita/ekonomi/181212-lion-air-cuma-kena-sanksi-teguran/0/ accessed February 16, 2016; BBC, "Kementerian Perhubungan Jatuhkan Sanksi untuk Lion Air [Ministry of Transport sanctioned Lion Air]," http://www.bbc.com/indonesia/berita indonesia/2015/02/150220 sanksi lionair, accessed February 16, 2016.

35 Supreme Court of the Republic of Indonesia, “Decision No. 2130 K/Pdt/2013,” p. 12. Supreme Court of the Republic of Indonesia, “Decision No. 411/PDT.G/2013/PN.JKT.PST.," p. 24-25.

${ }^{36}$ Indonesian Regulation No. 77, arts. 9-10. 
Using Thai Carriers' Services for Domestic Scheduled Routes of $2010^{37}$ (hereinafter referred to as the "Announcement of 2010") applies only to a domestic scheduled flight operated by a Thai air carrier. Hence, even though at present only Thai national air carriers perform domestic air services, foreign air carriers which may do so in the future if law permits are not regulated under this announcement. Moreover, any international route, regardless of whether the air carrier departs from an airport situated in the territory of Thailand, is not regulated by the Announcement of 2010. Hence, there is a chance that passengers who travel from the same airport and face a similar flight disruption are treated differently only because one is on a domestic flight while the other travels abroad. This can happen even if they are carried by the same air carrier.

Another defect of the Announcement of 2010 is that a domestic or international charter flight was not covered. Due to the limited scope of the announcement at that time, in 2012 approximately 400 Thai passengers on a charter flight operated by PC Air had been left stranded at an airport in South Korea for more than 24 hours since the airport refused to let the Thai-licensed air carrier to take off. ${ }^{38}$ Accordingly, Thailand passed the Announcement of the Ministry of Transport on Protection of Passenger Rights related to Charter Flight Services ${ }^{39}$ in 2013 (hereinafter the "Charter Announcement of 2013"). In spite of filling the loophole on international and domestic charter flight services, the Charter Announcement of 2013, basing its jurisdiction on the Thai operating license, fails to cover any foreign air carrier which operates a charter flight service from an airport situated in the territory of Thailand. ${ }^{40}$

Both announcements protect passengers in case of a flight delay and a flight cancellation, but only the Announcement of 2010 covers an event of denied boarding. The drafters of the Charter Announcement of 2013 did not see a reason to regulate this because a tour agency will check a number and conditions of passengers beforehand and a possibility of denied boarding in a charter flight is almost zero.

A flight delay under both announcements means "a flight that operates later than the scheduled flight timetable".11 Hence, calculation of the length of delay is based on the waiting time before the flight in question is resumed. Not all durations of delay entitle compensation under both announcements, only a delay of more than two hours triggers the protection. A delay of more than six hours equals a flight cancellation in terms of passenger protection. The difference is on classification of the length of delay in each announcement. As seen in Table V, while the Announcement of 2010 categorizes the waiting time due to a flight delay into four classes, the Charter Announcement of 2013 roughly divides them into two classes. Moreover, passengers on a delayed charter flight are not entitled to the same right to refund or reschedule and the right to compensation as passengers on a delayed scheduled flight. It is assumed that the drafters of the Announcement of 2010 may have been inspired by the European Court of Justice ${ }^{42}$ (ECJ) decision in Sturgeon v. Condor and Bock $v$ Air France hence the announcement only compensates passengers in the event of

37 Thailand, Announcement of the Ministry of Transport on Protection of Passenger Rights Using Thai Carriers' Services for Domestic Scheduled Routes, B.E. 2553 (2010) (Royal Gazette No. 129, Special Part 128 Ngor).

${ }^{38}$ Nation Multimedia, "PC Air Ordered to Suspend Flight," http://www.nationmultimedia.com/national/PC-air-ordered-to-suspend-flight-30192607.html, accessed February 19, 2016.

39 Thailand, Announcement of the Ministry of Transport on Protection of Passenger Rights Related to Charter Flight Services, B.E. 2556 (2013) (Royal Gazette No. 130, Special Part 90 Ngor).

40 Charter Announcement of 2013, section 3.

41 Announcement of 2010, section 2. See also Charter Announcement of 2013, section 2.

${ }^{42}$ Since 2013 the European Court of Justice has been referred to as the Court of Justice of the European Union. 
experiencing a delay of more than five hour. ${ }^{43}$

In relation to a flight cancellation, both announcements add a duty to provide accommodation if the next flight will depart on the following day of the original schedule of the former flight. ${ }^{44}$ Again, the right to compensation is excluded in the event of cancellation of a charter flight in all cases because from the drafters' point of view of a contractual relationship in a charter flight whereby a passenger enters into a contract with a tour agency, not an airline. ${ }^{45}$

Denied boarding under the Announcement of 2010 creates the same rights as a flight cancellation. ${ }^{46}$ However, the practical problem is that the rights are subject to being denied on any unreasonable ground, whereas airlines normally claim that the reason is not discriminatory and that it is fair.

An airline is free from compensating when a disruption is a result of an unexpected situation beyond the control of an airline (force majeure) ${ }^{47}$ Unfortunately, no conclusive definition on the expression "unexpected situation beyond the control of an air carrier" is given in details. At best, the Announcement of 2010 provides examples which include political situations, weather conditions, and unapproved strikes. ${ }^{48}$ However, the force majeure does not exempt an air carrier from a duty to care and also to refund or reschedule. In mid-February 2016, Nok Air cancelled nine scheduled domestic flights following an unapproved pilot strike. ${ }^{49}$ Although the right to compensation under the Announcement of 2010 does not cover this case as a result of being an unexpected event, passengers can bring a private right of action against the airline.

With regard to bomb threat, one may argue that the flight cannot operate according to the schedule as a result of the bomb threat procedures. However, an air carrier is free from liability since they must comply with the international standard to ensure safety of all passengers on board. Nevertheless, passengers flying domestic flights in Thailand are still entitled to the right to care, reschedule or refund since they are covered under the Thai announcements.

${ }^{43}$ Court of Justice of the European Union, "Joined Cases C-402/07 and C-432/07."

${ }^{44}$ Announcement of 2010, section 5(2)(c). See also Charter Announcement of 2013, section 7(3)(c).

45 Thailand, Announcement of the Ministry of Transport on Protection of Passenger Rights Using Thai Carriers' Services for Domestic Scheduled Routes, B.E. 2553 (2010) (Royal Gazette No. 129, Special Part 128 Ngor), section 5(3)(c).

${ }^{46}$ Announcement of 2010, section 5.

${ }^{47}$ Announcement of 2010, sections 4(3)(b), 5(3)(c).

${ }^{48}$ Announcement of 2010, section 4(3)(b).

49 Bangkok Post, "Pilot Strike Grounds Nok Air Flights," http://www.bangkokpost.com/news/transport/863552/pilot-strike-grounds-nok-air-flights, accessed February 19, 2016. 
Table 5

\begin{tabular}{|c|c|c|}
\hline $\begin{array}{c}\text { Delay and } \\
\text { Cancellation } \\
\text { Categories }\end{array}$ & Condition & Compensation \\
\hline \multicolumn{3}{|c|}{ Scheduled flight } \\
\hline First & $\begin{array}{l}\text { Between two and } \\
\text { three hours }\end{array}$ & $\begin{array}{l}\text { Providing: } \\
\quad \text { - food and drinks; and } \\
\text { - } \quad \text { communication facilities. } \\
\text { Refunding the air fare and other fees in full amount (cash) if a } \\
\text { passenger does not wish to proceed to fly. A refund in form other than } \\
\text { cash can be done only with an advance consent. }\end{array}$ \\
\hline \multirow{3}{*}{ Second } & \multirow[b]{2}{*}{$\begin{array}{l}\text { Between three } \\
\text { and five hours }\end{array}$} & $\begin{array}{l}\text { Providing: } \\
\quad \text { - } \quad \text { food and drinks; and } \\
\text { - } \quad \text { communication facilities. }\end{array}$ \\
\hline & & $\begin{array}{l}\text { Offering the following options: } \\
\text { - } \text { refunding the air fare and other fees in full amount(cash) if } \\
\text { a passenger does not wish to proceed to fly. A refund in form } \\
\text { other than cash can be done only with an advance consent; } \\
\text { - rescheduling the flight to the destination or the alternative } \\
\text { destination without any additional charge; or } \\
\text { - } \\
\text { travelling with other appropriate means of transport to the } \\
\text { destination without any additional charge. }\end{array}$ \\
\hline & \multirow[b]{2}{*}{$\begin{array}{l}\text { Between five and } \\
\text { six hours }\end{array}$} & Applying the same rule as the second category. \\
\hline Third & & $\begin{array}{l}\text { Providing compensation in cash for THB } 600 \text { (approximately USD17) } \\
\text { except when the airline can prove that the delay is caused by an } \\
\text { unexpected situation beyond the control of the airline. }\end{array}$ \\
\hline Fourth & $\begin{array}{l}\text { More than six } \\
\text { hours }\end{array}$ & Following the rules in relation to flight cancellation. \\
\hline
\end{tabular}


Cancellation

and denied

boarding

Offering the following options:

- $\quad$ refunding the air fare and other fees in full amount (cash)

if a passenger does not wish to proceed to fly. A refund in form other than cash can be done only with an advance consent; or

rescheduling the flight to the destination as specified in the ticket or to alternative destination close to the original destination within the same day, the next day or any other day as requested by the passenger.

Providing:

- food and drinks;

- communication facilities; and

- a hotel room for at least one night and a transportation between the airport and hotel if the new flight is scheduled to depart later than the original schedule for one day.

Providing compensation in cash for THB1,200 (approximately USD34) except when the airline can prove the following:

- the airline has notified the passengers about the cancellation of flight not less than three days prior to the departure date;

- the airline has notified the passenger about the cancellation of flight prior to the departure date less than three days but arrival time of the new offered flight is less than three hours difference (+- 3 hours); or

- the cancellation of flight is caused by an unexpected situation beyond the control of the airline (force majeure) such as political situations, bad weather, security, any other situation that may affect the safety of flight operations of aircraft and passengers. Italso includes a situation such as when a large number of staff take unapproved time off work or any other act undertakenby staff of an organization related to the services of the airline.

\begin{tabular}{|c|c|c|}
\hline \multicolumn{3}{|c|}{ Chartered flight } \\
\hline First & $\begin{array}{l}\text { Between two and } \\
\text { six hours }\end{array}$ & $\begin{array}{l}\text { Providing: } \\
\begin{aligned} & \text { food and drinks; and } \\
- & \text { communication facilities. }\end{aligned}\end{array}$ \\
\hline Second & $\begin{array}{l}\text { More than six } \\
\text { hours }\end{array}$ & Following the rules in relation to the cancellation of flight. \\
\hline \multirow{3}{*}{ Cancellation } & $\begin{array}{l}\text { Three days prior } \\
\text { to the schedule }\end{array}$ & $\begin{array}{l}\text { Informing passengers or tour agency. } \\
\text { Refunding airfares and other fees. }\end{array}$ \\
\hline & $\begin{array}{l}\text { Between one and } \\
\text { three days prior } \\
\text { to the schedule }\end{array}$ & $\begin{array}{l}\text { Informing passengers or tour agency. } \\
\text { Offering the following options: } \\
\begin{array}{cl}\text { - } & \text { refunding the air fare and other fees in full; or } \\
\text { - } & \text { rescheduling the flight to the destination or any alternative } \\
\text { destination without any additional charge. }\end{array}\end{array}$ \\
\hline & $\begin{array}{l}\text { Less than one } \\
\text { day prior to the } \\
\text { schedule or after } \\
\text { the schedule }\end{array}$ & $\begin{array}{l}\text { Providing: } \\
\begin{array}{c}\text { - } \\
\text { - } \\
\text { communication facilities. }\end{array} \\
\text { Providing accommodationfor at least one night and transportation } \\
\text { between the airport and hotel if the new flight is scheduled to depart } \\
\text { later than the original schedule for one day or more. }\end{array}$ \\
\hline
\end{tabular}


In order to prevent any abuse of right to compensation, the Announcement of 2010 only allows an airline to compensate in the form of a travel voucher when the passenger agrees in advance under a written form..$^{50}$ When an airline fails to comply with the announcement, the passenger is entitled to lodge a complaint to the Civil Aviation Authority of Thailand. ${ }^{51}$ However, this announcement does not specify any time limitation. Moreover, it does not guarantee the length of the investigation process.

The Charter Announcement of 2013 takes another approach due mainly to the PC Air event. Even though the Charter Announcement of 2013 lacks a provision on complaint procedure, it commands a precondition to a charter airline to submit a letter of bank guarantee with sufficient value for the entirety of charter flight services; accordingly, in case of refund and other expenses beyond the airline's capability to pay, such bank guarantee can be used..$^{52}$ The enforcement measure for a scheduled or charter airline that fails to care for a passenger is considered as failure to comply with the conditions attached to the air operating license. ${ }^{53}$ Accordingly, a penalty of up to one year imprisonment or a fine of up to THB20,000 (approximately USD1,680), or both, can be imposed. ${ }^{54}$ Thus far, such sanction has never been imposed on any airline in Thailand. However, an airline's operating license was suspended once due to its failure to take care of its passengers. ${ }^{55}$

As of 2016, in practice there has been no record of any complaint in relation to flight disruptions or penalties. In any case, the complaint under either of the above mentioned two announcements does not bar a passenger to pursue a private right of action. Before the entry into force of the International Carriage by Air Act ${ }^{56}$ (hereinafter referred to as the "International Carriage Act"), the Thai Civil and Commercial Code and a contract of carriage had been the basis of claim. After the entry into force of the International Carriage Act, ${ }^{57}$ an action for compensation for flight delay is under the exclusivity of this act. ${ }^{58}$ Since the latter has been in force for less than a year, there has not been any judgment on this exclusivity issue to date. It remains to be seen whether Thailand will follow the European Union's approach or rule that the International Carriage Act preempts any remedy. ${ }^{59}$

\section{Today's Magna Carta in International Carriage by Air: The Warsaw Conven- tion of 1929 and the Montreal Convention of 1999}

Air transport has an international nature which leads to many different applications of law and many different jurisdictions. It calls for harmonization on certain liabilities under a contract on international air carriage; and it is governed by international conventions, namely the Convention for the Unification of Certain Rules Relating to International Carriage by Air of $1929^{60}$ (hereinafter referred to as the "Warsaw

\footnotetext{
50 Announcement of 2010, sections 4(3), 6.

51 Announcement of 2010, section 10.

52 Charter Announcement of 2013, sections 4, 16.

53 Announcement of 2010, preamble.

${ }^{54}$ Thailand, Declaration of the Revolutionary Council No. 58, B.E. 2515 (27 January 1972) (Royal Gazette
} No. 2515/15/3 Por.), order nos. 4, 7,9, 16.

55 "PC Air Ordered to Suspend Flight," http://www.nationmultimedia.com/national/PC-air-orderedto-suspend-flight-30192607.html, accessed March 3, 2016.

56 Thailand, International Carriage by Air Act, B.E. 2558 (2015) (Royal Gazette No. 132 Part 10 Kor).

57 International Carriage Act, section 2. The act comes into force after the expiration of ninety days from the date of its publication in the Government Gazette, February 13, 2015.

${ }^{58}$ International Carriage Act, section 54.

59 See Part IV below. Court of Justice of the European Union, “Case C-344/04.”

${ }^{60}$ Convention for the Unification of Certain Rules Relating to International Carriage by Air, Warsaw, 12 October 1929. 
Convention") and the Convention for the Unification of Certain Rules for International Carriage by Air of $1999^{61}$ (hereinafter referred to as the "Montreal Convention"). The Warsaw Convention and the Montreal Convention similarly apply to a passenger only if a journey is held between two Contracting States; or within a Contracting State if there is an agreed stopping place within the territory of another State. ${ }^{62}$

With an objective to harmonize the rules in international air transport, both conventions contain similar provisions in relation to types of an air carrier's liability and those excluded from the scope of liability. The Warsaw Convention clearly unifies the liability rules by forcing an injured person to bring any action for damages that are subject to the conditions and limits under this convention solely. ${ }^{63}$ This concept is followed and elaborated upon in more detail by its successor, the Montreal Convention. ${ }^{64}$ In short, any action for damages under the purview of these two international conventions must be claimed under them solely.

Delay is under the scope of liability under both the Warsaw and Montreal Convention. ${ }^{65}$ Hence, both conventions provide the sole remedy for delay. ${ }^{66}$ The Warsaw Convention relieves an air carrier from liability if it proves it took "all necessary measures" to avoid the damage or it was impossible to do so. ${ }^{67}$ The Montreal Convention replaces the first relief with if an air carrier proves that it took "all measures that could reasonably be required to avoid the damage" and leaves the second claim untouched. ${ }^{68}$ While the defense in the Warsaw Convention seems a standard one, the revised one in the Montreal Convention makes more sense because if all necessary measures as required in the Warsaw Convention are taken, the damage cannot occur. ${ }^{69}$

Neither of the above mentioned two conventions defines delay. Actually, the drafters of the Montreal Convention intended not to define it. ${ }^{70}$ It is viewed that delay implies a discrepancy between the expected time and the actual time at which the carrier performs its duties. ${ }^{71}$ In this case, even though neither of the above mentioned two conventions literally covers flight cancellation and denied boarding, they can fit into the regime of delay. This is because in instances of both cancellation and denied boarding, a passenger cannot travel on the flight that such person expects an airline to perform the duties under the contract of carriage between them. One may partially argue that in case of denied boarding, an airline operates a flight but only a person is denied to board such flight so it is not delay on an airline's side. However, from the passenger's side, the contract is not performed. Such interpretation of nonfeasance and misfeasance is not uniform either in an academic world or among judiciary circles. At the end of the spectrum, a cancellation and denied boarding are considered as a nonfeasance and both conventions only cover the misfeasance of the contract of

${ }^{61}$ Convention for the Unification of Certain Rules for International Carriage by Air, Montreal, May 28, 1999, United Nations Treaty Series, Vol 2242, No. 33917.

${ }^{62}$ The Warsaw Convention, art 1; the Montreal Convention, art 1.

63 Ibid., art 24.

64 The Montreal Convention, art 29.

65 The Warsaw Convention, art 19. See also The Montreal Convention, art 19.

${ }^{66}$ Paul B. Larsen et al., Aviation Law Cases, Laws and Related Sources (Leiden: Martinus Nijhoff Publishers, 2012), p. 340.

67 The Warsaw Convention, art 20.

68 The Montreal Convention, art 19.

69 Paul S. Dempsey and Michael Milde, International Air Carrier Liability: The Montreal Convention of 1999 (Montreal: McGill University, 2005), p. 177.

${ }^{70}$ Jae Woon Lee and Joseph Charles Wheeler, "Air Carrier Liability for Delay: A Plea to Return to International Uniformity," Journal of Air Law and Commerce 77 (Winter, 2012), p. 50.

${ }^{71}$ I.H.Ph. Diederiks-Verschoor, revised by Pablo Mendes de Leon and Michael Butler, An Introduction to Air Law (Alphen aan den Rijn: Kluwer Law International, 2012), p. 175. 
carriage, in this case a delay. ${ }^{72}$

Dempsey and Johansson acknowledge this confusing concept as a result from a different view toward the concept of delay between Anglo-American law and Continental law. ${ }^{73}$ While the former covers non-performance of contract into the notion of delay, the latter does not. ${ }^{74}$ Accordingly, the decisions of courts are varied. Cases on denied boarding have mostly involved overbooking or bumping. Courts in Osmas Erdem v. Germanair ${ }^{75}$ and King v. American Airlines ${ }^{76}$ ruled that denied boarding was considered as delay. If bumping is on a return flight, it is a delay. ${ }^{77}$ On the contrary, other courts adjudicated that a provision on delay did not apply to denied boarding because it was a breach of contract under domestic law. ${ }^{78}$ In an event of flight cancellation, the rulings are more uniform than those in case of denied boarding. Flight cancellation constitutes a non-performance of contract. This holds true even in a cancellation of a return flight due to a strike. ${ }^{79}$ Since it is a non-performance of contract, it falls outside the scope of the conventions; therefore, the applicable law is a domestic law. ${ }^{80}$

From these case laws, it is possible that denied boarding lies under the Warsaw Convention or the Montreal Convention. Certainly delay comes under these two conventions. The question is whether the scope of passenger protection as provided in Indonesia and Thailand are preempted by the scope under both conventions. It is worth noting that in the United States, a passenger has an option to receive compensation provided for by the regulation and relieve an air carrier from further liability or to seek any restitution under applicable law. ${ }^{81}$ So it links a compensation scheme to the Warsaw Convention or the Montreal Convention in the case of an event occurring on an international flight.

\section{Comparison Between Indonesia and Thailand: Lessons from Each Neighbor and the Magna Carta}

In recent years, airline passengers' rights protection in Indonesia and Thailand seems to be heading on a similar path. Both countries have enacted or amended their legal framework related to this issue. It must be kept in mind that the differences between these two countries, especially in their respective legal systems and aviation business practices, have led to different approaches to ensure airline passengers' rights.

Both Indonesian and Thai legal framework have defined what a flight delay is. Following this milestone, flight delays are classified into several categories based on duration. While in Indonesia it is classified into six categories; in Thailand delay

\footnotetext{
72 Jorn J. Wegter, "The ECJ Decision of 10 January 2006 on the Validity of Regulation 261/2004: Ignoring the Exclusivity of the Montreal Convention," Air and Space Law 31, no. 2 (April 2006), p. 139.

73 Paul Stephen Dempsey and Svante O. Johansson, "Montreal v. Brussels: The Conflict of Laws on the Issue of Delay in International Air Carriage," Air and Space Law 35, no. 3 (2010), p. 210.

${ }^{74}$ Ibid.

75 Osman Erdem v. Germanair, District Court (1971) (Landgericht)

Düsseldorf, Federal Republic of Germany, cited in I.H.Ph. Diederiks-Verschoor, revised by Pablo Mendes de Leon and Michael Butler, "An Introduction to Air Law," p. 183.

${ }^{76}$ King v. Am. Airlines, Inc. (2002) 2d Cir.

77 Paradis v. Ghana Airways Ltd (2004) SDNY.

${ }^{78}$ Wogel v Mexicana Airlines (1987) 7th Cir.; Weiss v. El Al Israel Airlines, Ltd. (2006) SDNY.

79 Mullaney v. Delta Air Lines (2009) SDNY.

${ }^{80}$ Ibid.

8114 CFR 250, sec 250.9 - written explanation of denied boarding compensation and boarding priorities, and verbal notification of denied boarding compensation (2012).
} 
categories depend on the nature of the flight, whether it is a scheduled or chartered flight. Within the Thai legal framework, delay is classified into four categories for the former and into two categories for the latter. Airline passengers' rights are more strongly protected in Thailand since chartered passengers are also covered and clearly mentioned in its legal framework, namely the Charter Announcement of 2013. It must be highlighted, that unlike in Thailand, Indonesian Regulation No. 89 only regulates delay compensation for scheduled flights, thus leaving chartered or nonscheduled flight passengers unprotected. However, Indonesian Regulation No. 89 has a broader scope compared to the Thai announcements since it is also applicable for international flights departing from any Indonesian airport, while the latter is only applicable for domestic flights.

Speaking of the compensation amount, a question arises as to whether IDR300,000 (approximately USD25) still meets today's standard. This is the same value as was determined by Indonesian Regulation No. 77, the predecessor of the current Indonesian Regulation No. 89, between 2011-2015, thus ignoring inflation and posing the depreciation burden on passengers. At the same tim,e the compensation amount in Thailand is similar to the one in Indonesia. It is 'only' THB600 (approximately USD17) for a delay between five and six hours or THB1,200 (approximately USD34) for flight cancellation or denied boarding. Such a 'small' compensation amount leaves a doubt whether it is adequate to cover passengers' basic needs or damages. Unlike in Thailand, there is no compensation for flight cancellation in Indonesia.

At the very least, in Thailand the airline is obliged to provide communication facilities when a flight delay, cancellation, or denied boarding case occurs. Such kind of obligation does not exist within the Indonesian legal framework.

Unfortunately, the Indonesian legal framework fails to distinguish between delay and flight cancellation. There is no further comprehensive provision on flight cancellation \in Indonesian Regulation No. 89. As a result, there are numerous perspectives for a situation, for example: flight cancellation after twelve hours' delay. No doubt there is an ambiguity whether the latter situation is merely a flight cancellation, or a consecutive act which contains flight cancellation as well as delay. Therefore, Indonesian airlines, including other foreign airlines departing from any Indonesian airport, could use this loophole to neglect their obligation to fulfill their passengers' rights. 
The absence of setting up a maximum limit of delay impacts the definition of flight cancellation. It is considered as the ultimate stage of delay within the Indonesian legal framework; while in Thailand, cancellation and delay are clearly treated separately as two different issues. Such a 'simple' yet important issue needs to be settled if there will be an ASEAN legal framework on airline passengers' in regards to flight delay, cancellation, and denied boarding in the coming years.

Speaking of right to care, airline passengers flying domestic flights are more protected in Thailand than in Indonesia. Neither of the above stated two Thai announcements distinguish reasons of delay, thus the airline must provide food and drinks for any category of delay no matter the cause, ranging from the airline management's fault to bad weather (force majeure). However, force majeure is the exception for the airline to not grant compensation. The latter situation is 180 degrees different from that in Indonesia, where there must be a fault on the airline's part in order to trigger right to care and compensation.

At the moment, Indonesia has already ratified the Montreal Convention. Thailand finds itself more 'sovereign' by not ratifying any of these conventions, leaving international flight passengers protection solely to Thai national law and reducing state (actor) responsibility. However, there are discussions to ratify the Montreal Convention in Thailand within recent years, ${ }^{82}$ in order to protect airline passengers' more.

Finally, law enforcement remains one of the main issues in both countries. Lack of sanctions towards airlines which clearly fail to fulfill their obligation seems to be the norm. Publication records on sanctions are also not easily accessible, thus leaving a hard task for protecting passengers' rights.

\section{UNIFORMITY OF AIRLINE PASSENGERS' RIGHTS THROUGH A REGIONAL INITIATIVE LEGAL FRAMEWORK: IS IT JUST A DREAM?}

\section{A. EU Regulation No. 261/2004: Establishing an Example for Others}

The $\mathrm{EU}^{83}$, as a regional initiative, takes another approach under Regulation (EC) $261 / 2004^{84}$ (hereinafter referred to as "EU Regulation No. 261"), which provides the right to care, refund, reroute, and compensation. This is quite similar to the scope of the Indonesian and Thai legal framework. In International Air Transport Association and European Low Fares Airline Association v. Department for Transport, the Court

82 Thailand, Cabinet Resolution dated 18 February 2015 on approval for accession to the Montreal Convention 1999 subject to the fact that Thailand revises its International Carriage by Air Act, B.E. 2558 (2015).

${ }^{83}$ The aims set out in the EU treaties are achieved by several types of legal act. Some are binding, others are not. Some apply to all EU countries, others to just a few. The nature of a "regulation" means it must be applied in its entirety across the EU; thus it is a binding legislative act. There are some others which are less binding, namely i.) directive (a legislative act that sets out a goal that all EU countries must achieve. However, it is up to the individual countries to devise their own laws on how to reach these goals); ii.) decision (binding on those to whom it is addressed, either an EU country or an individual company, and is directly applicable); iii.) recommendation (not binding - it allows the institutions to make their views known and to suggest a line of action without imposing any legal obligation on those to whom it is addressed); and iv.) opinion (an instrument that allows the institutions to make a statement in a non-binding fashion; in other words without imposing any legal obligation on those to whom it is addressed). European Union, "Regulations, Directives, and other acts," http://europa.eu/eu-law/decision-making/legal-acts/index en.htm, accessed May 30, 2016.

${ }^{84}$ European Union, Regulation (EC) No 261/2004 of the European Parliament and of the Council of 11 February 2004 establishing common rules on compensation and assistance to passengers in the event of denied boarding and of cancellation or long delay of flights, and repealing Regulation (EEC) No 295/91, L 46/1. 
of Justice of the European Union (CJEU) upheld that EU Regulation No. 261 did not violate the Montreal Convention. ${ }^{85}$ From the CJEU's viewpoint, the regulation is of a public nature while the Montreal Convention is of a private one and both aim to recover damage with a different approach. The CJEU distinguished damage in case of delay into two types: one is identical to all passengers and the other is individual damage. ${ }^{86}$ The Montreal Convention provides a channel of claim for the latter damage while EU Regulation No. 261 provides a scope of protection for the damage sustained to all passengers. Hence the scope is dissimilar and not preempted by the Montreal Convention. ${ }^{87}$ This reasoning is also applied for the right to compensation which is not trumped by the Montreal Convention. ${ }^{88}$

In short, EU Regulation No. 261 is a measure to protect during the pre-flight or delay on departure while the Warsaw Convention and the Montreal Convention provide post-flight or delay on arrival remedy. It must be highlighted that several air law scholars criticize this judgment. They affirm that the Montreal Convention precludes consumer protection measures because of the exclusivity clause. ${ }^{89}$ On the contrary, from the EU law's perspective, this judgment is sound and clarifies the relationship between public law and private international law. ${ }^{90}$

It needs to be duly noted that damage from delay under EU Regulation No. 261 does not literally include compensation. ${ }^{91}$ The CJEU subsequently applied this reasoning to the right to compensation which is not trumped over by the Montreal Convention and expanded the right to compensation in case of delay for more than three hours. ${ }^{92}$ This broad expansion led to increasing criticism on disregarding the exclusivity principle under the Warsaw Convention and Montreal Convention and rewriting the law. ${ }^{93}$

The protective measures under EU Regulation No. 261 have given rise to many disputes between air carriers and passengers, so it is under revision to clarify and balance the rights and obligations. Consumer protection measures include the right to compensation in the event of long delays; the right to information about flight disruption; and the rights when missing a connecting flight. ${ }^{94}$ At the same time, the financial capacities of airlines are taken into account by the drafters; thus the proposal limits the obligation to compensation in case of long delay based on distance of the route as well as confines the duty to offer an accommodation. ${ }^{95}$ Yet, in spite of this effort to balance rights and duties, it is not an exaggeration to say that even though

${ }^{85}$ Court of Justice of the European Union, “Case C-344/04.”

${ }^{86}$ Ibid.

87 Ibid.

${ }^{88}$ Court of Justice of the European Union, “Case C-204/08."

89 Wegter, "The ECJ Decision,” p.146; Dempsey and Johansson, “Montreal v. Brussels,” p. 219-220; Lee and Wheeler, "Air Carrier Liability for Delay," p. 65-67.

90 Kieran St. Clair Bradley, "Case C-344/04, The Queen ex parte International Air Transport Association, European Low Fares Airline Association v. Department for Transport, Judgment of the Court (Grand Chamber) of 10 January 2006, nyr," Common Market Law Review, 43 (2006), p. 1124.

91 EU Regulation No. 261, art 6.

92 Court of Justice of the European Union, “Case C-204/08.”. Court of Justice of the European Union, "Joint Cases C-402/07 and C-432/07."

${ }^{93}$ John Balfour, "Airline Liability for Delays: The Court of Justice of the EU Rewrites EC Regulation 261/2004," Air and Space Law 35, no. 1 (2010), p. 75; Kinga Arnold and Pablo Mendes de Leon, "Regulation (EC) 261/2004 in the Light of the Recent Decisions of the European Court of Justice: Time for a Change?!," Air and Space Law 35, no. 2 (2010), p. 326.

${ }^{94}$ European Union, Proposal for a Regulation of the European Parliament and of the Council amending Regulation (EC) No 261/2004 establishing common rules on compensation and assistance to passengers in the event of denied boarding and of cancellation of long delay of flights and Regulation (EC) No. 2027/97 on air carrier liability in respect of the carriage of passengers and their baggage by air, 2013/0072 (COD), art 1.

95 Ibid. 
the aviation sector and scholars have raised concerns about the overlapping remedies by international and regional law, in particular on delay, the proposal for revising EU Regulation No. 261 has still provided passengers' protection in cases of delay.

\section{B. Will There Be An 'ASEAN 261'?}

The ASEAN Multilateral Agreement on Air Services ${ }^{96}$ and ASEAN Multilateral Agreement on the Full Liberalization of Passenger Air Services ${ }^{97}$ contain no specific provisions on airline passengers' protection, even though this issue is one of the key economic elements in ASAM. According to the implementation framework of ASAM, neither the ASEAN Air Transport Working Group nor other specialized transport groups are responsible for implementing consumer protection, which has to be governed by an ASEAN all-sector approach by 2015. ${ }^{98}$ In other words, it falls under the jurisdiction of the ASEAN Committee on Consumer Protection (ACCP).

The ACCP has fostered consumer protection within ASEAN since 2007. ${ }^{99}$ Under the ASEAN Economic Community Blueprint, the measures adopted by the ACCP concern the notification and information of exchange mechanism, cross border consumer redress mechanisms, and capacity building. ${ }^{100}$ From these measures, the ACCP is silent on central legislation on consumer protection in ASEAN. With regard to the aviation industry, there are no laws dictating the protection of air passengers. In its policy digest as to which objective should enhance consumer protection illustrated in case studies, only issues dealing with low-fare airlines on misleading and unfair practices are explained. ${ }^{101}$

Speaking of the chance establishing a uniformity of passengers' rights protection in ASEAN, it is most likely that this regional initiative will not be entirely able to 'duplicate' EU Regulation No. 261. It seems that 'ASEAN 261', in terms of compensation, could not be successfully implemented in the future so-called intra-ASEAN flights, considering the nature of differences between ASEAN and EU. Huge disparities in living standards among the member states, for example between Singapore and Myanmar, would be one of the main barriers apart from the legal enforcement issue which has no effective watch dog at the moment. The financial viability and different financial capability among the member states' airlines should also be taken into account. This point was raised while preparing ASEAN Open Skies, especially regarding new entrant carriers. ${ }^{102}$ Failure to do so means putting too much pressure on the ASEAN airline industry, which could discourage its growth and corresponding benefits for the member states' economic development. Moreover, excluding the compensation scheme will prevent any possible debate on conflict with the Warsaw Convention or the Montreal Convention. In addition, promoting right to care to passengers whose flight is disrupted could enhance the airline's reputation. Hopefully ASEAN will be

96 ASEAN, ASEAN Multilateral Agreement on Air Services, Manila, 20 May 2009.

97 ASEAN, ASEAN Multilateral Agreement on the Full Liberalization of Passenger Air Services, Bandar Seri Begawan, 12 November 2010.

${ }_{98}$ International Civil Aviation Organization, "Implementation Framework Of The Asean Single Aviation Market," http://www.icao.int/APAC/Meetings/2013 APSAPG3/Flimsy\%202\%20ASAM\%20Implementation\%20Framework.pdf, accessed March 1, 2016.

99 ASEAN Secretariat, Consumer Protection Digests and Case Studies: A Policy Guide (Vol. I) (Jakarta: ASEAN Secretariat, 2014), p. iii.

100 Yue Chia Siow and Michael G. Plummer, ASEAN Economic Cooperation and Integration: Progress, Challenges and Future Directions (Cambridge: Cambridge University Press, 2015), p. 117.

101 ASEAN Secretariat, "Consumer Protection Digest," pp. 93-98.

102 Peter Forsyth et al., Preparing ASEAN for Open Sky, AADCP Regional Economic Policy Support Facility Research Project 02/008 (Jakarta: Regional Economic Policy Support Facility, 2004), pp. 46-47. 
able to learn from EU Regulation No. 261 and also its amendment proposal ${ }^{103}$ which put too much pressure on the European airline industry.

Considering such situation, an 'ASEAN 261' shall consist only of right to care, such as beverages, food, communication, and accommodation. Any kind of compensation shall be excluded in order to encourage all member states to implement this legal framework. Success in achieving it shall mean establishing ASEAN as a regional initiative which promotes the passengers' right to care.

\section{CONCLUSION AND THE WAY FORWARD}

The liberalization process in ASEAN is in progress, however, passengers' rights are falling behind. Flight delay, cancellation, and denied boarding have become a phenomenon in recent years, especially in Indonesia and Thailand. Bomb threats are another emerging issue that contributes to flight disruptions. Domestic laws already regulate these issues despite the absence of a regional initiative's legal framework. However, legal enforcement is still in question.

With regards to international flights, at least the passengers' right to compensation is already covered by the Magna Carta in international carriage by air, namely the Warsaw Convention and Montreal Convention. Nevertheless, the right to care is left unregulated in both of the said conventions. In the EU, Regulation No. 261 has become the guardian of passengers' rights. On the other hand, it puts (too much) pressure on airlines operating within the scope of the said regulation.

As for ASEAN, there is an urgency to harmonize different legal frameworks in order to protect passengers' rights. However, ASEAN should not entirely follow Regulation No. 261 due to the nature of differences between ASEAN and the EU. A proposal is being put forward to serve as a solution, namely establishing an ASEAN legal framework for passengers' rights. The most important thing to attract the member states to implement the relevant provision is to exclude compensation. Such legal framework shall only consist of the right to care, namely meal, beverage, communication facilities, and even accommodation.

Hopefully, an equilibrium can be maintained in order to encourage the continuous growth of the aviation industry with its positive impact on developing the member states' economies.

\section{ACKNOWLEDGEMENT}

First, the author would like to thank the Indonesia Endowment Fund for Education (Lembaga Pengelola Dana Pendidikan) - the Indonesian Ministry of Finance, the Republic of Indonesia for its scholarship and funding support for this research.

Second, the author would like to thank the Anandamahidol Foundation for funding her Ph.D study and research in air and space law.

${ }^{103}$ European Union, Proposal for a Regulation of the European Parliament and of the Council amending Regulation (EC) No 261/2004 establishing common rules on compensation and assistance to passengers in the event of denied boarding and of cancellation of long delay of flights and Regulation (EC) No 2027/97 on air carrier liability in respect of the carriage of passengers and their baggage by air, 2013/0072 (COD). 


\section{Bibliography}

\section{Legal Documents}

ASEAN Multilateral Agreement on Air Services, Manila, 20 May 2009.

ASEAN Multilateral Agreement on the Full Liberalization of Passenger Air Services, Bandar Seri Begawan, 12 November 2010.

Convention for the Unification of Certain Rules for International Carriage by Air. Montreal, May 28, 1999. United Nations Treaty Series. Vol 2242. No. 33917.

Convention for the Unification of Certain Rules Relating to International Carriage by Air, Warsaw, October 12, 1929.

Court of Justice of the European Union. "Case C-204/08."

Court of Justice of the European Union. "Case C-344/04."

Court of Justice of the European Union. "Joined Cases C-402/07 and C-432/07."

European Union. Proposal for a Regulation of the European Parliament and of the Council amending Regulation (EC) No 261/2004 establishing common rules on compensation and assistance to passengers in the event of denied boarding and of cancellation of long delay of flights and Regulation (EC) No 2027/97 on air carrier liability in respect of the carriage of passengers and their baggage by air, 2013/0072 (COD).

European Union. Regulation (EC) No 261/2004 of the European Parliament and of the Council of 11 February 2004 establishing common rules on compensation and assistance to passengers in the event of denied boarding and of cancellation or long delay of flights, and repealing Regulation (EEC) No 295/91, L 46/1.

Federal Republic of Germany. District Court (Landgericht) Düsseldorf. Osman Erdem v. Germanair, 1971.

Indonesia. Peraturan Menteri Perhubungan tentang Penanganan Keterlambatan Penerbangan (Delay Management) Pada Badan Usaha Angkutan Udara Niaga Berjadwal di Indonesia [Minister of Transportation Regulation regarding Delay Management on Scheduled Commercial Airline in Indonesia]. Permenhub No. 89 Tahun 2015, BNRI No. 716 Year 2015 [Minister of Transportation Regulation No. 89 Year 2015, SG No. 716 Year 2015].

---. Peraturan Menteri Perhubungan tentang Tanggung Jawab Pengangkut Angkutan Udara [Minister of Transportation Regulation regarding the Responsibility of Airlines]. Permenhub No. 77 Tahun 2011, BNRI No. 486 Year 2011 [Minister of Transportation Regulation No. 77 Year 2011, SG No. 486 Year 2011].

---. Undang-Undang tentang Penerbangan [Law regarding Aviation]. UU No. 1 Tahun 2009, LN No. 1 Year 2009 [Law No. 1, SG. No. 1 Year 2009].

Supreme Court of the Republic of Indonesia. "Decision No. 2130 K/Pdt/2013."

---. "Decision No. 411/PDT.G/2013/PN.JKT.PST."

Thailand. Act on Certain Offences Against Air Navigation. B.E. 2521 (1978). (Royal Gazette No. 95, Part 87 Special Issue).

---. Act on Certain Offences Against Air Navigation. B.E. 2558 (2015). (Royal Gazette No. 132, Part 10 Kor).

---. Air Navigation Act. B.E. 2497 (1954).

---. Announcement of the Ministry of Transport on Protection of Passenger Rights Related to Charter Flight Services. B.E. 2556 (2013). (Royal Gazette No. 
130, Special Part 90 Ngor).

---. Announcement of the Ministry of Transport on Protection of Passenger Rights Using Thai Carriers' Services for Domestic Scheduled Routes. B.E. 2553 (2010).

(Royal Gazette No. 129, Special Part 128 Ngor).

---. Cabinet Resolution dated 18 February 2015 on approval for accession to the Montreal Convention 1999 subject to the fact that Thailand revises its International Carriage by Air Act, B.E. 2558 (2015).

---. Declaration of the Revolutionary Council No. 58. B.E. 2515 (27 January 1972).

(Royal Gazette No. 2515/15/3 Por.).

---. International Carriage by Air Act. B.E. 2558 (2015). (Royal Gazette No. 132, Part 10 Kor).

---. Penal Code. B.E. 2499 (1956). (Royal Gazette No. 73, Part 95, Special Issue Page 1).

United States Court of Appeals 2nd Circuit. King v Am. Airlines, Inc., 2002

United States Court of Appeals 7th Circuit. Wogel v Mexicana Airlines, 1987.

United States Court Southern District of New York. Mullaney v Delta Air Lines, 2009

---. Weiss v El Al Israel Airlines, Ltd., 2006.

---. Paradis v Ghana Airways Ltd, 2002.

\section{Books}

Abeyratne, Ruwantissa. Aeronomics and Law: Fixing Anomalies. Heidelberg: Springer, 2012.

Abeyratne, Ruwantissa. Regulation of Air Transport: The Slumbering Sentinels. Heidelberg: Springer, 2014.

ASEAN Secretariat. Consumer Protection Digests and Case Studies: A Policy Guide (Vol. I). Jakarta: ASEAN Secretariat, 2014.

Dempsey, Paul S. and Michael Milde. International Air Carrier Liability: The Montreal Convention of 1999. Montreal: McGill University, 2005.

Diederiks-Verschoor, I. H. Ph. (revised by Pablo Mendes de Leon and Michael Butler). An Introduction to Air Law Alphen aan den Rijn: Kluwer Law International, 2012.

Forsyth, Peter et al. Preparing ASEAN for Open Sky, AADCP Regional Economic Policy Support Facility Research Project 02/008. Jakarta: Regional Economic Policy Support Facility, 2004.

Larsen, Paul B. et.al. Aviation Law Cases, Laws and Related Sources. Leiden: Martinus Nijhoff Publishers, 2012.

Siow, Yue Chia and Michael G. Plummer. ASEAN Economic Cooperation and Integration: Progress, Challenges and Future Directions. Cambridge: Cambridge University Press, 2015.

\section{Articles}

Arnold, Kinga and Pablo Mendes de Leon. "Regulation (EC) 261/2004 in the Light of the Recent Decisions of the European Court of Justice: Time for a Change?!." Air and Space Law 35, no. 2 (2010): 91-112.

Balfour, John. "Airline Liability for Delays: The Court of Justice of the EU Rewrites EC Regulation 261/2004." Air and Space Law 35, no. 1 (2010): 71-75.

Bradley, Kieran St. Clair. "Case C-344/04, The Queen ex parte International Air Transport Association, European Low Fares Airline Association v. 
Department for Transport, Judgment of the Court (Grand Chamber) of January 10, 2006, nyr." Common Market Law Review 43 (2006): 11011124.

Dempsey, Paul Stephen and Svante 0. Johansson. "Montreal v. Brussels: The Conflict of Laws on the Issue of Delay in International Air Carriage." Air and Space Law 35, no. 3 (2010): 207-224.

Lee, Jae Woon and Joseph Charles Wheeler. "Air Carrier Liability for Delay: A Plea to Return to International Uniformity." Journal of Air Law and Commerce 77 (Winter 2012): 43-103.

Wegter, Jorn J. "The ECJ Decision of 10 January 2006 on the Validity of Regulation 261/2004: Ignoring the Exclusivity of the Montreal Convention." Air and Space Law 31, no. 2 (April 2006): 133-148.

\section{Websites}

Bandara Online. "10 Bandara Angkasa Pura II Over Kapasitas [10 Angkasa Pura II's airport are overcapacity]" http://bandaraonline.com/airport/10bandara-angkasa-pura-ii-over-kapasitas. Accessed February 15, 2016.

Bangkok Post. "Pilot Strike Grounds Nok Air Flights." http://www.bangkokpost. com/news/transport/863552/pilot-strike-grounds-nok-air-flights. Accessed February 19, 2016.

BBC. "Kementerian Perhubungan Jatuhkan Sanksi untuk Lion Air [Ministry of Transport sanctioned Lion Air]." http://www.bbc.com/indonesia/ berita indonesia/2015/02/150220 sanksi lionair. Accessed February 16, 2016.

Belarminus, Robertus. "Dikejar-kejar Penumpang, Petugas Lion Air Kabur [Chased by Passengers, Lion Air Officer Escaped]." http://megapolitan.kompas. com/read/2015/02/19/14342341/Dikejar-kejar.Penumpang.Petugas. Lion.Air.Kabur. Accessed February 16, 2016.

Cahyono, Hari. "Awas, Lampu Kuning Kondisi Aviasi Indonesia." [“Beware, Yellow Light for the Condition of Indonesian Aviation"]. http://beritatrans. com/2016/02/11/awas-lampu-kuning-kondisi-aviasi-indonesia/. Accessed February 15, 2016.

Coconuts. "Thai Lion Air Seeks THB2 Million Compensation from Flirty Bomb Joker." http://bangkok.coconuts.co/2015/11/04/lion-air-ceo-seeks-thb2million-compensation-flirty-bomb-joker. Accessed February 17, 2016.

Diebelius, Georgia. "Pilot Banned from Flying After 'Offering Divorced Air Hostess as Compensation for a Delay on a Flight to Bali." http://www.dailymail. co.uk/travel/travel news/article-3326809/Pilot-banned-flyingoffering-divorced-AIR-HOSTESS-compensation-delay-flight-Bali.html. Accessed February 15, 2016.

European Union. "Regulations, Directives, and Other Acts." http://europa.eu/eu-law/ decision-making/legal-acts/index en.htm. Accessed May 30, 2016.

Fokus Riau. "Delay 7 Jam, Penumpang Obrak-Abrik Ruang Duty Manager Lion Air [7 Hours Delay, the Passengers Vandalized Lion Air's Duty Manager Room]." http://fokusriau.com/berita-delay-7-jam-penumpang-obrakabrikruang-duty-manager-lion-air-.html. Accessed February 16, 2016.

Gresnews. "Lion Air Cuma Kena Sanksi Teguran [Lion Air is only sanctioned with warning]." http://www.gresnews.com/berita/ekonomi/181212-lionair-cuma-kena-sanksi-teguran/0/. Accessed February 16, 2016.

HukumOnline. "Lima Kasus Maskapai Penerbangan yang Dibawa ke Pengadilan [Five 
Airline Cases Brought to the Court] http://www.hukumonline.com/ berita/baca/lt54d046d9261ac/lima-kasus-maskapai-penerbanganyang-dibawa-ke-pengadilan. Accessed February 15, 2016.

HukumOnline. "Waspada! Bercanda Soal Bom di Pesawat Bisa Dipenjara [Beware! Bomb Hoax on Board of an Airplane Can End up in Prison] http://www. hukumonline.com/berita/baca/lt568e24c702bd1/waspada-bercandasoal-bom-di-pesawat-bisa-dipenjara. Accessed February 214, 016.

International Civil Aviation Organization. "Implementation Framework Of The Asean Single Aviation Market." http://www.icao.int/APAC/Meetings/2013 APSAPG $3 /$ Flimsy $\% 202 \% 20$ ASAM $\% 20$ Implementation $\% 20$ Framework.pdf. Accessed March 1, 2016.

Kompas. "Delay 5 Jam, Lion Air Tak Berikan Kompensasi untuk Penumpang [Five hour delay, Lion Air did not give the compensation for the passengers]. http:// nasional.kompas.com/read/2015/01/05/01135611/Delay.5.Jam.Lion. Air.Tak.Berikan.Kompensasi.untuk.Penumpang. Accessed February 16, 2016.

Mardira, Salman. "Uang Kompensasi Tak Sesuai, Penumpang Lion Air Protes [Compensation Not Adequate, Lion Air Passnger Protests]." http://news. okezone.com/read/2015/12/01/340/1258703/uang-kompensasitak-sesuai-penumpang-lion-air-protes?page=1. Accessed February 16, 2016.

Nation Multimedia. “Bangkok Airways Flight Delayed Following Bomb Hoax.” http:// www.nationmultimedia.com/breakingnews/Bangkok-Airways-flightdelayed-following-bomb-hoax-30274777.html. Accessed February 17, 2016.

———. "PC Air Ordered to Suspend Flight." http://www.nationmultimedia.com/ national/PC-air-ordered-to-suspend-flight-30192607.html. Accessed February 19, 2016.

Primadhyta, Safyra and Elisa Valenta Sari. "Ignasius Jonan Bebaskan Lion Air dari Sanksi Pembekuan Izin [Ignasius Jonan Releases Lion Air from the Sanction of License Revocation]." http://www.cnnindonesia.com/ ekonomi/20150220220007-92-33711/ignasius-jonan-bebaskan-lionair-dari-sanksi-pembekuan-izin/. Accessed February 16, 2016.

Putra, Erik Purnama. "Menhub Jonan Dituding Takut Hadapi Lion Air. [Minister of Transportation Jonan Accused of Being Afraid to Encounter Lion Air]." http://www.republika.co.id/berita/nasional/umum/15/02/21/ nk3rxo-menhub-jonan-dituding-takut-hadapi-lion-air. Accessed February 16, 2016.

Satu Maluku. "Bercanda Bom, Penumpang Tujuan Langgur Terancam Penjara 9 Tahun [Joking about bomb, a passenger bound for Langgur facing jail sentence of 9 years]." http://satumaluku.com/2015/12/05/bercanda-bompenumpang-tujuan-langgur-terancam-penjara-9-tahun/. Accessed February 14, 2016.

_-_. "Kasus Candaan Bom, Polisi Didesak Periksa Anak Nono Sampono [The bombjoke case, Police urged to investigate Nono Sampono's children]." http:// satumaluku.com/2015/12/08/kasus-candaan-bom-polisi-didesakperiksa-anak-nono-sampono/. Accessed February 15, 2016.

Siwalima News. "Usut Kasus Bercanda Bawa Bom di Pesawat: DPRD Desak Polisi Periksa Anak Nono Sampono." [Investigating the Case of Bomb Hoax on Airplane: The Regional House of Representatives Urges the Police to Examine the Son of Nono Sampono"]. http://www.siwalimanews. com/post/dprd desak polisi periksa anak nono sampono. Accessed 
February 15, 2016.

Suryowati, Estu. "Menhub Pastikan yang Bercanda Bawa Bom di Bandara Tetap Diproses Hukum [Minister of Transportation Reassures that the Legal Process against Enactors of Bomb Hoax on Airflight Will Continue] http://bisniskeuangan.kompas.com/ read/2016/01/16/150026826/Menhub.Pastikan.yang.Bercanda. Bawa.Bom.di.Bandara.Tetap.Diproses.Hukum. Accessed February $14,2016$.

Suwarjono. "Terlambat 5 Jam, Lion Air Tolak Beri Kompensasi [Delay for 5 hours, Lion Air Refuses to Grant Compensation]." http://www.suara.com/ news/2015/02/23/164731/terlambat-5-jam-lion-air-tolak-berikompensasi. Accessed February 16, 2016.

Thairath. "Air Asia Bomb Threat." http://www.thairath.co.th/content/446016. Accessed February 17, 2016.

The Embassy of the Republic of Indonesia in Ottawa. "Kepentingan Indonesia untuk Mencapai Transportasi Udara Berkelanjutan [Indonesia's Interest to Achieve Sustainable Air Transport]." http://www. indonesia-ottawa.org/2013/03/kepentingan-indonesia-untukmencapai-transportasi-udara-berkelanjutan/. Accessed March 3, 2016.

The Jakarta Post. "Lion Air Flight Canceled after Passenger Makes Bomb Joke." http://www.thejakartapost.com/news/2015/11/02/lion-airflight-canceled-after-passenger-makes-bomb-joke.html. Accessed February 17, 2016.

The Phuket News. "Thai Man, 20, Arrested, Charged for Sarcastic 'Shoe Bomb' Remarks During Airport Security Inspection." http://www. thephuketnews.com/thai-man-20-arrested-charged-for-sarcasticshoe-bomb-remarks-during-airport-security-inspection-55727. php. Accessed February 17, 2016. 